\title{
CAUSES OF REWORK IN CONSTRUCTION PROJECTS IN UKRAINE
}

\author{
R. TRACH ${ }^{1}$, K. PAWLUK ${ }^{2}$, M. LENDO-SIWICKA ${ }^{3}$,
}

\begin{abstract}
The collapse of the Soviet Union was the cause of a significant decline in many economies of the newly created countries. However, many of them, including the Ukrainian economy, are slowly recovering. One of the largest branches of the economy in this country is construction, which, despite political turmoil, is constantly growing, especially in the private real estate development sector. Despite the fact that the construction market is constantly developing, it is limited by the costs of rework and alterations resulting from many reasons. The key negative effects of modifications to the results of the project are exceeding the budget and time of project implementation, dissatisfaction with the project team, violation of contractual requirements and lowering the quality of the final product. Therefore, the purpose of this article was to determine the reasons for the emergence of rework in the in Ukraine by analyzing the results of surveys conducted among construction enterprises.
\end{abstract}

Keywords: rework, causes of rework, survey, construction project

\section{INTRODUCTION}

The disintegration of the Soviet Union in 1991 forced 15 countries forming the Union to sudden transition from a regulated economy to the free market phase. The transition from economic planning based on communists to a market economy still requires restructuring at all levels $[1,2]$. It was partly related to the wholesale import of various theories, strategies, and operational plans, including newly minted marketing division [3]. However, the market share of industry in

\footnotetext{
${ }^{1} \mathrm{PhD}$., Warsaw University of Life Sciences, Faculty of Civil Engineering and Environmental Engineering, ul. Nowoursynowska 159,02-776 Warsaw, Poland, e-mail: roman_trach@sggw.pl

${ }^{2} \mathrm{PhD}$., Eng., Warsaw University of Life Sciences, Faculty of Civil Engineering and Environmental Engineering, ul. Nowoursynowska 159,02-776 Warsaw, Poland, e-mail: katarzyna_pawluk@sggw.pl

${ }^{3} \mathrm{PhD}$., Eng., Warsaw University of Life Sciences, Faculty of Civil Engineering and Environmental Engineering, ul. Nowoursynowska 159,02-776 Warsaw, Poland, e-mail: marzena_lendo_siwicka@sggw.pl
} 
the Ukrainian economy has dropped significantly since the end of the Soviet Union, by about $50 \%$ [4]. Although a progress in the Ukraine economic environment has been made, the continuing conflict in the East of Ukraine has further deteriorated. Because of the actions taken in 2015, current GDB in the end of 2018 was 3\% [4]. In Figure 1 the main indicators of Ukraine economy is showed.

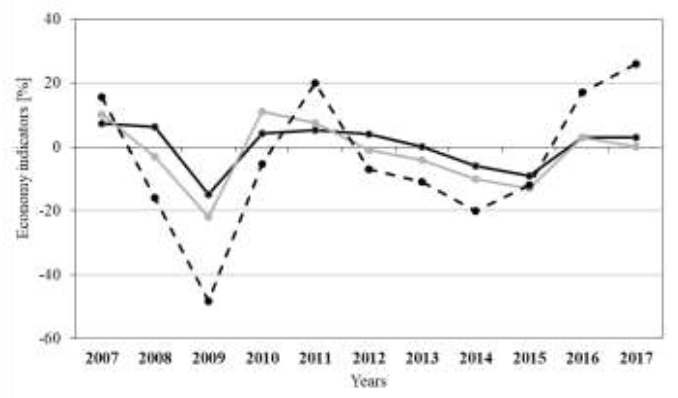

Fig 1. Indicators of the Ukraine economy as a percentage of last year [4]

Nowadays, the construction industry is one of the most significant components of the Ukraine economy. It is ranked number one by the profit index, among other sectors of Ukrainian economy, and it has shown significant progress in recent years [3]. The building industry contributed to the country's economic growth with an expansion of $25 \%$ in 2017. The development of the construction environment in Ukraine is driven by a private sector (Fig. 2), which is due to high investment needs in housing real estate [5].

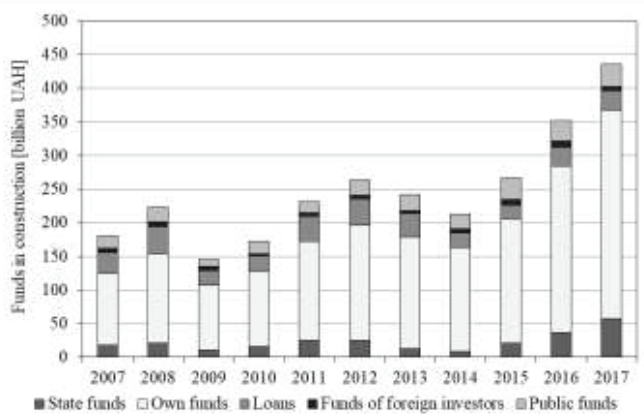

Fig 2. Funds in construction, in billion UAH [4]

The size and apparent growth of Ukraine's construction industry triggered the need of cost analysis for construction projects, especially in terms of reworks. The reworks are the common phenomenon 
having a significant impact on construction process performance, which could be defined in accordance to Love and $\mathrm{Li}[6]$ as the "The unnecessary effort of re-doing a process or activity that was incorrectly implemented the first time". On the Ukraine's construction market there is a trend to accepted rework as an integral part of construction activities. This is related to the mismanagement during the design and build stage, which causes repetition of some activity, or identifies serious weaknesses in the end of construction work. In order to have an idea of the scale of rework in the Ukrainian construction industry, the amount of funding from the state and local budgets under the item "Capital construction and rework" should be concerned. Accordingly, in 2017, capital works were carried out at the level of UAH 42.91 billion ( $\$ 1.53$ billion) while at the begging of 2018 the level of UAH 75.21 billion ( $\$ 2.68$ billion) was achieved [7]. If we assume that direct rework costs amount to about $10 \%$ of the project cost, then reworks in construction financed from the state budget amounted to 4.29 billion UAH ( $\$ 0.153$ billion) in 2017 and 7.52 billion UAH ( $\$ 0.268$ billion) in 2018. These are only the general costs of construction projects from state and local sources, excluding private funds, which are spent on construction and costs of rework. The indirect effects of the impact of rework are that the ripple effects of rework carried forward on different aspects such as reputation, stress, motivation and relationships. All these factors affect the budget of a construction project and have to be considered under several studies. In connection with the above, this article attempts to identify the causes of rework in construction projects in Ukraine. Therefore, the purpose of this article was to determine the reasons for the emergence of rework in the in Ukraine by analyzing the results of surveys conducted among construction enterprises.

\section{REWORK IN CONSTRUCTION - LITERATURE REVIEW}

There are limited studies in the area of rework in construction studies, especially in terms of cost control and identification of cost of reworks in construction industry. This is a crucial issue since the rework during construction process leads to the waste of resources. Thus, the adverse consequences of rework include reduced profit, loss of market share and reputation, increased turnover of management and workforce, lower productivity, higher costs, and, all too frequently, costly litigation between participants over responsibility for overruns and delays [8]. Love et al. [9] in their longitudinal and extensive "rework in construction" study based on 260 construction projects reported that rework costs of $11.07 \%$ of the original contract value as well as errors and omissions in contract documentation were two of the most highly correlated causes of rework. The level of rework in construction projects depends on external factors such as excessive workload 
and market conditions. Increased defects and poor workmanship may arise from limitations on the availability of good subcontractors and workers, and, additional or unwarranted, pressures for early completion. As an example, Josephson and Hammarlund [10] reported that the cost of rework on construction projects ranged from $2 \%$ to $6 \%$ of the contract values. On the other hand, Burati et al. [11] indicated that quality deviations accounted for an average of $12.4 \%$ of the contract value.

Moreover, rework could lead to a considerable addition of a project's time and cost overrun, especially during the construction stage. For poorly managed projects, the overall impact of rework may be equal to or even exceed the estimated profit margin [12-15]. Rework has both direct and indirect effects on the performance of construction projects. The direct effect of the impact of rework are: additional time for rework, additional costs of rework, additional materials spent on rework and control next waste, additional labour for rework, difficulty of managing resources.

The varying interpretations and definitions of rework have led to a lack of uniformity in rework data collation and quantification. Arguably, the measurement of rework costs in itself does not result in improvement, but it merely provides the starting point for establishing new knowledge [16]. As a result of differences in definitions, scope, data collection methods used these numbers are not fully comparable, however they give some idea of the scale of rework. To reduce the impact of reworks there is a need to understand their basic reason for their existence or set of conditions that stimulate their occurrence in a building process. Basically, a rework can result from various sources such as errors, omissions and changes, which are defined as [17]:

Errors - any item or activity in a system that is performed incorrectly resulting in a deviation. Errors are often not readily identifiable and often only become evident. Rework is exacerbated by errors made during the design process, errors which then appear downstream in the procurement process. The extent of rework required, then, depends on how long the error has remained unnoticed. The longer the error goes undetected, the greater the likelihood of rework occurring that significantly impacts cost and schedule. The dimensional error or collision contained within design documentation may not arise until the project is being physically constructed on-site.

Omission - any part of a system including design, construction, and fabrication, that has been left out resulting in a deviation. Omission errors arise when the process of action control is subjected to strain or distraction. Failure to undertake procedural tasks during the design process and continual design reuse are cause to omission errors. The work practices implemented by organizations can aggravate similar errors, regardless of the skills and experiences of the people involved in a project. Examples include time pressure, understaffing, fatigue and inexperience. A typical example is the study conducted by Love et al. [18] to investigate the anatomy of omission errors in construction 
and resource engineering projects. The study revealed that the issue of design fees was identified by respondents in the construction sector as a factor contributing to an omission and design-related rework. Contractors and subcontractors are also susceptible to omission errors, as quality, safety and environmental management system constraints may not always be strictly adhered to, and as a result, tasks or processes may need to be reworked.

Change - a directed action altering the currently established requirements. The change is essentially a directed action that alters current established requirements. Changes can have an effect on the aesthetics and functional aspects of the building, the scope and the nature of work, or its operational aspects. Changes can have a negative impact on productivity and project performance. Designrelated rework in the form of changing the orders is the major source of rework in construction projects.

In several studies, the causes of rework in construction were classified in different ways. Devis et al. [19] categorized the sources of rework as owner, designer, vender, transporter and, constructor. Burati et al. [11] mentioned five main fields of rework: design, transportation, manufacturing, construction and feasibility. Josephson et al. [20] classified the rework causes by categories and influences in rework costs and singled out: design, production management, workmanship, material, client, and machines. However, the classification proposed by Love and Edwards [21] included the following elements:

1. Client-related factors: including lack of experience and knowledge of design and construction process, lack of client involvement in the project, lack of funding allocated for site investigations, inadequate briefing, inadequacies in contract and documentation, and poor communication with design consultants.

2. Design-related factors: including ineffective use of quality management practices, poor coordination between different design team members, ineffective use of information technologies, lack of manpower to complete the required tasks, poor planning of workload, time boxing/ fixed time for a task, staff turnover/ re-allocation to other projects, insufficient time to prepare contract documentations, incomplete design at the time of a tender, and inadequate client brief to prepare the detailed contract documentation.

3. Subcontractor related factors: such as defects, damages, poor workmanship, use of poorquality materials, inadequate managerial skills and specific problems associated with multilayered subcontracting.

4. Other factors: such as constructability associated concerns, poor site conditions, and environmental parameters. E.g. setting out errors, changes in construction methods to 
improve constructability, failure to provide protection to construction works and omissions of some activity or task.

This classification in the opinion of many specialist is the most reflected on the character of rework's causes.

\section{RESEARCH METHOD}

The survey is a flexible research method used to investigate a root of problem, to confirm the need for obtain research into a topical issues and to deliver an appropriate tool to resolve them [22]. To identify the causes of rework surveys were conducted in 42 Ukrainian construction industries. The examination covered real estate developers, design offices and contractors enterprises from western and central region of Ukraine. A questionnaire has been sent via e-mail to representatives of companies throughout the period of February to July 2018, while collection of answers that are included in this paper was completed on August, 2018. The total number of collected questionnaires was 59. The surveys were carried out with the main participants of the construction investment process: owner (16 surveys), designer (17 surveys) and contractor (26 surveys). The studies were based on Love and Edwards [21], Mastenbroek [23] and Meshksar [24] research.

The questionnaire was divided into two parts, where the first one included personal information of a respondent (including gender, educational qualification, occupation, years of experience and the type of project that the company takes). The second part had a form of a checklist of the rework causes that occurred during a project thanks to which the respondents had no possibility to omit some of them, while the questionnaire would have the form of open questions. This part of questionnaire was basically composed of three main blocks: coordination and project management, design and economy. The respondents were requested to rate the causes of rework on construction projects using a 5-point Likert scale, where: 1- very low impact, 2- low , 3 - average, 4 - high, and 5- very high impact. Based on the collected questionnaires from all of the participants, the percentage of individual responses to a question of "Causes of rework" sorted according to the grading scale was calculated. The weighted average (WA) for particular "Causes" was computed in such a way that the sum of responses was divided by the number of questionnaires and multiplied by $100 \%$. Based on the values of weighted average the rating of "Causes" was conducted. 


\section{RESULTS AND DISCUSSION}

In this study, besides finding what causes were relevant for the studied projects, it was also important to find the gravity of the causes and rank them by importance. The results of the survey accordingly to the group of project participants are presented in Tables 1-3.

Table 1. The owner related factors

\begin{tabular}{|c|c|c|c|c|c|c|c|c|c|c|c|c|}
\hline \multirow{3}{*}{ Causes of rework } & \multicolumn{10}{|c|}{ The grading scale } & \multirow{3}{*}{ WA } & \multirow{3}{*}{ Rating } \\
\hline & \multicolumn{2}{|c|}{1} & \multicolumn{2}{|r|}{2} & \multicolumn{2}{|c|}{3} & \multicolumn{2}{|r|}{4} & \multicolumn{2}{|r|}{5} & & \\
\hline & No & $\%$ & No & $\%$ & No & $\%$ & No & $\%$ & No & $\%$ & & \\
\hline Lack of coordination and poor communication & 1 & 6.3 & 2 & 12.5 & 2 & 12.5 & 5 & 31.3 & 6 & 37.5 & 3.8 & 1 \\
\hline Design change is initiated by the owner & 1 & 6.3 & 2 & 12.5 & 1 & 6.3 & 7 & 43.8 & 5 & 31.3 & 3.8 & 2 \\
\hline $\begin{array}{l}\text { Lack of experience and knowledge of the design } \\
\text { and construction process }\end{array}$ & 1 & 6.3 & 2 & 12.5 & 6 & 37.5 & 4 & 25.0 & 3 & 18.8 & 3.4 & 3 \\
\hline Lack of funding allocated for site investigations & 1 & 6.3 & 3 & 18.8 & 4 & 25.0 & 5 & 31.3 & 3 & 18.8 & 3.4 & 4 \\
\hline Lack of client involvement in the project & 2 & 12.5 & 3 & 18.8 & 3 & 18.8 & 5 & 31.3 & 3 & 18.8 & 3.3 & 5 \\
\hline $\begin{array}{l}\text { Insufficient time and money spent on the briefing } \\
\text { process }\end{array}$ & 3 & 18.8 & 2 & 12.5 & 5 & 31.3 & 3 & 18.8 & 3 & 18.8 & 3.1 & 6 \\
\hline $\begin{array}{c}\text { Expenditure on low fees for preparing contract } \\
\text { documentation }\end{array}$ & 3 & 18.8 & 2 & 12.5 & 6 & 37.5 & 3 & 18.8 & 2 & 12.5 & 2.9 & 7 \\
\hline
\end{tabular}

Table 2. The designer related factors

\begin{tabular}{|c|c|c|c|c|c|c|c|c|c|c|c|c|}
\hline \multirow{3}{*}{ Causes of rework } & \multicolumn{10}{|c|}{ The grading scale } & \multirow{3}{*}{ WA } & \multirow{3}{*}{ Rating } \\
\hline & \multicolumn{2}{|c|}{1} & \multicolumn{2}{|c|}{2} & \multicolumn{2}{|c|}{3} & \multicolumn{2}{|r|}{4} & \multicolumn{2}{|c|}{5} & & \\
\hline & No & $\%$ & No & $\%$ & No & $\%$ & No & $\%$ & No & $\%$ & & \\
\hline Incomplete design at the time of tender & 1 & 5.9 & 1 & 5.9 & 2 & 11.8 & 4 & 23.5 & 9 & 52.9 & 4.1 & 1 \\
\hline Poor coordination of design & 1 & 5.9 & 2 & 11.8 & 3 & 17.6 & 6 & 35.3 & 5 & 29.4 & 3.7 & 2 \\
\hline $\begin{array}{l}\text { Design change is initiated due to financial and } \\
\text { economic changes }\end{array}$ & 1 & 5.9 & 2 & 11.8 & 5 & 29.4 & 6 & 35.3 & 3 & 17.6 & 3.5 & 3 \\
\hline $\begin{array}{l}\text { Omissions of items from the contract } \\
\text { documentation }\end{array}$ & 1 & 5.9 & 2 & 11.8 & 5 & 29.4 & 7 & 41.2 & 2 & 11.8 & 3.4 & 4 \\
\hline Errors made in the contract documentation & 1 & 5.9 & 3 & 17.6 & 5 & 29.4 & 5 & 29.4 & 3 & 17.6 & 3.4 & 5 \\
\hline $\begin{array}{l}\text { Insufficient time to prepare contract } \\
\text { documentation }\end{array}$ & 2 & 11.8 & 2 & 11.8 & 4 & 23.5 & 7 & 41.2 & 2 & 11.8 & 3.3 & 6 \\
\hline $\begin{array}{l}\text { Inadequate client brief to prepare detailed contract } \\
\text { documentation }\end{array}$ & 3 & 17.6 & 3 & 17.6 & 4 & 23.5 & 5 & 29.4 & 2 & 11.8 & 3.0 & 7 \\
\hline $\begin{array}{l}\text { Insufficient skill levels to complete the required } \\
\text { task }\end{array}$ & 2 & 11.8 & 3 & 17.6 & 5 & 29.4 & 6 & 35.3 & 1 & 5.9 & 3.1 & 8 \\
\hline Ineffective use of information technologies & 2 & 11.8 & 4 & 23.5 & 5 & 29.4 & 4 & 23.5 & 2 & 11.8 & 3.0 & 9 \\
\hline
\end{tabular}


Table 3. The contractor related factor

\begin{tabular}{|c|c|c|c|c|c|c|c|c|c|c|c|c|}
\hline \multirow{3}{*}{ Causes of rework } & \multicolumn{10}{|c|}{ The grading scale } & \multirow{3}{*}{ WA } & \multirow{3}{*}{ Rating } \\
\hline & \multicolumn{2}{|c|}{1} & \multicolumn{2}{|c|}{2} & \multicolumn{2}{|c|}{3} & \multicolumn{2}{|c|}{4} & \multicolumn{2}{|c|}{5} & & \\
\hline & No & $\%$ & No & $\%$ & No & $\%$ & No & $\%$ & No & $\%$ & & \\
\hline Design change is initiated by the contractor & 3 & 11.5 & 1 & 3.8 & 1 & 3.8 & 7 & 26.9 & 14 & 53.8 & 4.1 & 1 \\
\hline $\begin{array}{l}\text { Change in construction methods in order to } \\
\text { improve constructability or due to site conditions }\end{array}$ & 2 & 7.7 & 2 & 7.7 & 3 & 11.5 & 10 & 38.5 & 9 & 34.6 & 3.8 & 2 \\
\hline Non-compliance with specification & 2 & 7.7 & 3 & 11.5 & 5 & 19.2 & 10 & 38.5 & 6 & 23.1 & 3.6 & 3 \\
\hline $\begin{array}{l}\text { Machine not working satisfactorily or breakdown } \\
\text { or defects }\end{array}$ & 3 & 11.5 & 3 & 11.5 & 5 & 19.2 & 10 & 38.5 & 5 & 19.2 & 3.4 & 4 \\
\hline Omission errors by construction personnel & 3 & 11.5 & 4 & 15.4 & 5 & 19.2 & 9 & 34.6 & 5 & 19.2 & 3.3 & 5 \\
\hline Poor planning and coordination of resources & 3 & 11.5 & 5 & 19.2 & 5 & 19.2 & 7 & 26.9 & 6 & 23.1 & 3.3 & 6 \\
\hline Shortage or low skilled of labor & 5 & 19.2 & 4 & 15.4 & 3 & 11.5 & 9 & 34.6 & 5 & 19.2 & 3.2 & 7 \\
\hline Lack of training and experience & 3 & 11.5 & 5 & 19.2 & 5 & 19.2 & 10 & 38.5 & 3 & 11.5 & 3.2 & 8 \\
\hline Defective workmanship & 4 & 15.4 & 6 & 23.1 & 5 & 19.2 & 6 & 23.1 & 5 & 19.2 & 3.1 & 9 \\
\hline
\end{tabular}

In all the tables all causes obtain WA values above 3.00, excluding the record of "Expenditure on low fees for preparing contract documentation" in Table 1 where it equals 2.9. Thus, all causes significantly contributed to rework. For the owner, the main factors were the "Lack of coordination and poor communication" (which implied very high effect of $37.5 \%$ ) and "Design change" (very high effect of $31.3 \%$ ), which in the ranking, were placed on first and second positions. The examples where the "Design changes" required by owner were recognized as the main cause of rework in construction projects $[10,11,17,25-27]$. The owner indicated the problem in project management and inadequate communication between all participants of the construction project. This issue might be related to insufficient professional experience in design and construction projects. It is highly unlikely that the owner was operating on the market before. The funding issue was not present as serious risk to reworks that occurred under the construction. However, deficiency in resources for field studies was indicated as a quite significant cause of rework (4 place in ranking).

The most ranked effects by designer were "Incomplete design at the time of tender" (which implied very high effect of 52.9\%) and "Poor coordination of design" (very high effect of $29.4 \%$ ). The lack of documentation errors and omissions could be induced by the lack of communication between the owner and the design team [21]. "Design change initiated by contractor" was also indicated as a major cause of rework according to contractor (very high effect of 53.8\%). "Change in construction methods" was ranked on second place (very high effect of 34.6\%) and "Non - compliance with 
specification" with third position in ranking (very high effect of $23.1 \%$ ) had direct impact of rework. All these "Causes" were forced by the above-mentioned reasons indicated by the owner and designer. This was due the fact that some part of the project was insufficient or unintelligible for the owner, so the project was re-defined by the designer in accordance with expectations of the investor. In the end, the implemented changes in the project were not understood by the contractors in the construction field [28]. However, for contractor respondents, the labour resources (their experience and management) in construction process were the least crucial factors of rework.

To sum up, the studies revealed that the highly ranked by all participants the main "Causes of rework" in Ukrainian construction market are divided in two group: coordination and design (Fig. $3)$. Therefore, this factor was recognised as the most important root of rework for all the participants of investment in several studies [21,27,28].

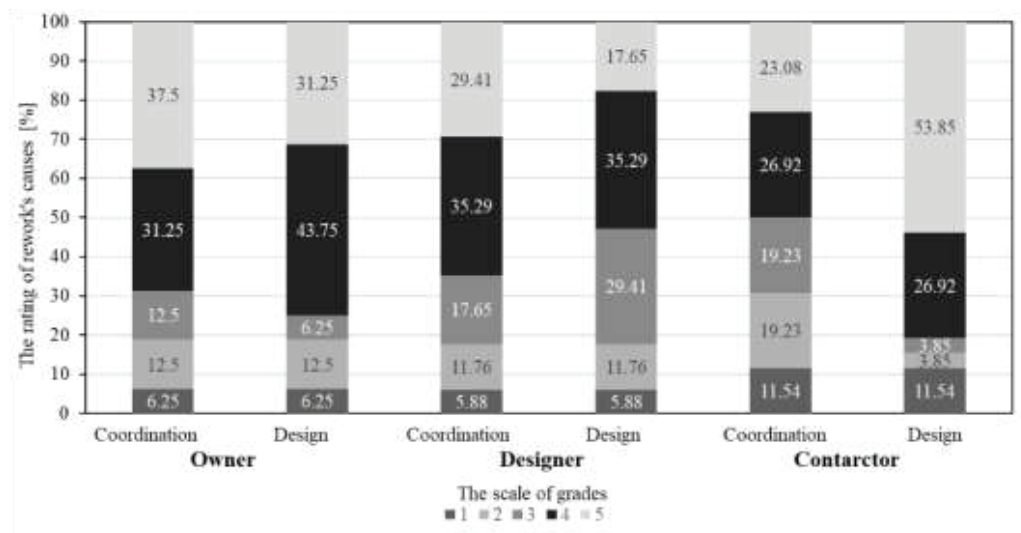

Fig. 3. The scale of causes of rework relating to the coordination and design with the division of the project participants in \% 


\section{Conclusions}

Rework has become an autonomic part of the investment construction process that directly conduct to time and cost overruns in projects. Therefore, the identification of the causes of construction rework is necessary in order to improve the performance of projects. This issue is vital especially in emerging economies, such as the Ukrainian, where the construction industry in considered one of its significant components. These preliminary studies conducted in 42 Ukrainian construction industries indicated the main factors of rework in perception of construction professionals. Based on the questionnaire results, the professionals perception was found to be similar. The causes with the highest effects were "Design change" and "Lack of coordination". For the owner the "Lack of coordination and poor communication" as well as "Design change" had a very high impact on rework process implementation (very high impact of $37.5 \%$ and $31.3 \%$, respectively). While, for the designer the "Incomplete design at the time of tender" and "Poor coordination of design" had the most significant impact on the occurrence of reworks (very high effect of $52.9 \%$ and $29.4 \%$, respectively). Moreover, for the contractors' respondents the "Design change initiated by contractor" was ranked in the first place of the list (very high effect of 53.8\%), while the "Poor planning and coordination of resources" was placed on sixth position in ranking (very high effect of $23.1 \%$ and high effect of $26.9 \%$ ). The funding issue (penultimate position in owner ranking) and participants skills (penultimate position in design and contractor ranking) were less important factors of rework, which had a relatively low impact in comparison with other causes. Furthermore, it appeared that all "Causes" resulted one from another. The lack of experience and knowledge of an owner, due to a lack of communication was a root cause of many design problems e.g. incomplete project, project change, omissions of items from the contract, errors made in the contract documentation, change in construction methods. Therefore, implementing the pre-project planning, project management and contractor management could be an efficient tool for the correct project realisation and, in consequence, reducing the root causes of rework. In future, the studies on relationship between rework, cost and time should be performed as integrated factor of overall cost. 


\section{REFERENCES}

1. K. L. B. Newman, "Organizational Transformation During Institutional Upheaval”, Academy of Management Review, 25: 602-620, 2000.

2. DD.J. Kim, P. Frederikson, B. Poland, "What U.S. Managers Need To Know”, Thunderbird International Business Review, 46 (3): 293-316, 2004.

3. E. Skliarenko, H. Bartel, "Evaluating the Relative Efficacy of the Marketing Function in the Construction Complex of Ukraine", International Advances in Economic Research, 12(1): 17-32, 2006.

4. State Statistics Service of Ukraine, 2018. Retrieved from: http://www.ukrstat.gov.ua.

5. N. Bibik, N. Dril, "Trends of Housing Construction Development in Ukraine: Retrospective and Contemporary Situation”, Baltic Journal of Real Estate Economics and Construction Management, 5(1): 51-61, 2017.

6. P.E.D. Love, H. Li, "Quantifying the causes and costs of rework in construction", Construction Management and Economics, 18 (4): 479-490, 2000.

7. Budget expenditures of Ukraine. (2018). Retrieved from http://cost.ua/budget/expenditure/elements/\#88

8. C. Eden, T. Williams, S. Howick, "The role of feedback dynamics in disruption and delay on the nature of disruption and delay (D\&D) in major projects", Journal of the Operational Research Society, 51 (3): 291-300, 2000 .

9. P.E.D. Love, I. Simpson, A. Hill, C. Standing, "From justification to evaluation: building information modeling for asset owners", Automation in Construction, 35: 208-216, 2013.

10. P Y. Hammarlund, P.E. Josephson, "Sources of quality failures in building. in Proceedings of the European Symposium on Management". Lisbon, Portugal: Quality and Economics in Housing and other Building Sectors, 1991.

11. J.L. Burati, J.J. Farrington, W.B. Ledbetter, "Causes of quality deviations in design and construction”, J. Constr. Eng. Manag., 118 (1): 34-49, 1992.

12. I. Rybka, E. Bondar-Nowakowska, K. Pawluk, M. Połoński,"Risk of contractors' claims on the example of road works", IOP Conference Series: Materials Science and Engineering, 245: 1-9, 2017.

13. R. Trach, M. Polonski, P. Hrytsiuk. "Modelling of Efficiency Evaluation of Traditional Project Delivery Methods and Integrated Project Delivery (IPD)”, IOP Conf. Series: Materials Science and Engineering 471 (2019) 112043, 2018.

14. A. Leśniak, M. Lendo-Siwicka, "Value engineering method in Polish construction", MATEC Web of Conferences, 196: 1-7, 2018

15. M. Lendo-Siwicka, M. Połoński, K. Pawluk, "Identification of the interference in the investment process during the realization of a shopping centre - a case study", Archives of Civil Engineering, LXII (1): 159-172, 2016.

16. G. D. Holt, D. Proverbs, P.E.D. Love, "Survey findings on UK construction procurement: Is it achieving lowest cost. or value?”, Building Construction Management Journal, 5 (2): 13-20, 2000.

17. P. Barber, A. Graves, M. Hall, D. Sheath, C. Tomkins, "Quality failure costs in civil engineering projects", Int. J. Qual. Manag. Reliab., 17 (4/5): 479-492, 2000.

18. P.E.D. Love, D.J. Edwards, Z. Irani, D.H.T. Walker, "Project pathogens: The anatomy of omission errors in construction and engineering projects", IEEE Transactions on Engineering Management, 56 (3): 425-435, 2009.

19. K. Davis, W.B. Ledbetter, J.L. Buratti, "Measuring design and construction quality costs", ASCE Journal of Construction Engineering and Management, 115 (3): 389-400, 1989.

20. P.E. Josephson, B. Larsson, H. Li, "Illustrative benchmarking rework and rework costs", Journal of Management in Engineering, 18(2): 76-83, 2002.

21. P.E.D. Love, D.J. Edwards, "Determinants of rework in building construction projects", Eng. Constr. Archit. Manag., 11(4): 259-274, 2004.

22. E. Radziszewska-Zielina, E. Kania, G. Śladowski, „Problems of the Selection of Construction Technology for Structures in the Centres of Urban Agglomerations", Archives of Civil Engineering, 64(1): 55-71, 2018.

23. Y.C. Mastenbroek, "Reducing rework costs in construction projects", Bachelor's thesis, University of Twente, Netherland, 2010.

24. S. Meshksar, "Cost and Time Impacts of Reworks in Building a Reinforced Concrete Structure", Master of Science thesis, Eastern Mediterranean University, Cyprus, 2012.

25. F.M. Arain, S.P. Low, "Developers' views of potential causes of variation orders for institutional buildings in Singapore”, Archit. Sci. Rev., 49 (1): 59-74, 2006.

26. B.-G. Hwang, S.R. Thomas, C.T. Haas, C.H. Caldas, "Measuring the impact of rework on construction cost performance", J. Constr. Eng. Manag., 135 (3): 187-198, 2009.

27. P.E.D. Love, P. Mandal, H. Li, "Determining the causal structure of rework influences in construction", Construction Management and Economics, 17:505-517, 1999.

28. B.G. Hwang, X. Zhao, K. J. Goh, "Investigating the client-related rework in building projects: The case of Singapore”, International Journal of Project Management, 32(4): 698-708, 2014. 


\section{LIST OF FIGURES AND TABLES:}

Fig. 1. Indicators the Ukraine economy as a percentage of last year

Rys. 1. Procentowe wskaźniki gospodarki Ukrainy ostatnich lat

Fig 2. Funds in construction, billion UAH

Rys. 2. Środki finansowe w budownictwie, miliard UAH

Fig. 3. The scale of causes of rework relating to the coordination and design with the division of the project participants in \%

Rys. 3. Skala przyczyn przeróbek związanych z koordynacją i projektowaniem z podziałem na uczestników projektu w \%

Tab. 1. The owner related factors

Tab. 1. Czynniki związane z właścicielem

Tab. 2. The designer related factors

Tab. 2. Czynniki związane z projektantem

Tab. 3. The contractor related factors

Tab. 3. Czynniki związane z wykonawcą 


\section{PRZYCZYNY ROBÓT NAPRAWCZYCH W PROJEKTACH BUDOWLANYCH NA UKRAINIE}

Slowa kluczowe: roboty naprawcze, przyczyny napraw, ankieta, projekt budowlany

\section{STRESZCZENIE :}

Upadek Związku Radzieckiego był przyczyną znacznego spadku ekonomicznego wielu gospodarek nowopowstałych państw. Jednakże, wiele z nich, w tym gospodarka Ukraińska odnotowuje powolny wzrost wskaźników gospodarczych. Jedną z największych gałęzi przemysłu w tym kraju jest budownictwo, które pomimo zawirowań politycznych charakteryzuje się stałym wzrost zwłaszcza w sektorze inwestycji deweloperskich i budowy prywatnych domów. Pomimo, że ukraiński rynek budowlany stale się rozwija i generuje znaczny zysk to jest on ograniczany przez koszty licznych robót naprawczych często występujących w trakcie trwania procesu inwestycyjnego. Jedną z przyczyn tego zjawiska jest przyzwolenie wszystkich uczestników procesu inwestycyjnego na powstawanie dodatkowych prac w trakcie lub po zakończeniu prac nad danym przedsięwzięciem.

Generalnie, w literaturze występują ograniczone badania dotyczące robót naprawczych w budownictwie, w szczególności z zakresu kontroli i identyfikacji kosztów. Problem jest jednak bardzo poważny, ponieważ konieczność przeprowadzenia dodatkowych prac czy to na etapie projektu czy też wykonania prowadzi do marnotrawstwa wielu zasobów. Na podstawie publikowanych danych przyjmuje się, że koszty tych robót wynoszą ok. $11 \%$ pierwotnej wartości zamówienia. Natomiast, kluczowymi negatywnymi skutkami ich występowania na wyniki przedsięwzięcia budowlanego są przekroczenia budżetu oraz czasu realizacji projektu, niezadowolenie z zespołu projektowego i wykonawczego, zwiększenie rotacji kadry zarządzającej i roboczej, niższa produktywność i jakości produktu finalnego, naruszenie wymagań umownych, kosztowne spory między uczestnikami w zakresie odpowiedzialności za przekroczenia i opóźnienia, spadek udziału w rynku i utrata reputacji przedsiębiorstw budowlanych.

Pomimo, że oszacowanie kosztów robót naprawczych nie prowadzi od razu do poprawy sytuacji, to stanowi punkt wyjścia do dalszych analiz. Niestety, różne interpretacje i terminy tych robót doprowadziły do niejednorodności kwantyfikacji danych i braku ich właściwego zestawienia. W wyniku różnic w definicjach, zakresie i stosowanych metodach zbierania danych, publikowane wartości liczbowe nie są w pełni porównywalne, jednakże dają pewne pojęcie o skali problemu związanego z koniecznością prowadzenia dodatkowych prac na każdym etapie realizacji inwestycji. W celu eliminacji robót naprawczych, w pierwszej kolejności należy określić źródło ich powstania i/lub zestaw warunków, które stymulują ich pojawianie się w procesie budowlanym. Zasadniczo, uważa się, że podstawowymi ich źródłami w przedsięwzięciach budowlanych są błędy, pominięcia i zmiany w dokumentacji projektowej. Natomiast, warunki determinujące ich pojawienie się, związane są przede wszystkim z otoczeniem głównych uczestników budowlanego procesu inwestycyjnego. Do czynników związanych z właścicielem zalicza się m. in. brak doświadczenia i wiedzy na temat projektu i procesu budowlanego, brak zaangażowania w projekt, brak środków finansowych na badania terenowe, niedociągnięcia w zapisach umowy oraz słaba komunikacja z pozostałymi uczestnikami. W przypadku projektanta warunki determinujące wystąpienia przeróbek i napraw dotyczą w głównej mierze nieskutecznego zarządzania, słabej koordynacji działań zespołu projektowego, nieefektywne korzystanie z technologii informatycznych, niedostatecznego czasu na przygotowanie dokumentacji kontraktowej, czy przygotowania niepełnego projektu w momencie składania ofert. Natomiast spośród czynników związanych z wykonawcami wymienia się takie jak: uszkodzenia i złe wykonanie, stosowanie materiałów o niskiej jakości, niewystarczające umiejętności kierownicze i problemy związane $z$ podwykonawstwem. 
W związku z powyższym, celem niniejszego artykułu było określenie przyczyn powstania robót naprawczych w inwestycjach realizowanych w Ukrainie poprzez analizę wyników ankiet przeprowadzonych wśród przedsiębiorstw z branży budowlanej. Ankiety sporządzono z uwzględnieniem czynników ich występowania i przeprowadzono wśród głównych uczestników procesu inwestycyjnego tj. właścicieli, projektantów i wykonawców. Wyniki badań wykazały, że do podstawowych przyczyn wystąpienia tych robót w procesie budowlanym według respondentów związanych z właścicielem należały m.in. brak koordynacji i słaba komunikacja oraz zmiany projektu. Głównymi ich stymulantami wskazanymi przez osoby związane z projektem były: niekompletna dokumentacja projektowa wysyłana do oferentów oraz złe zarządzanie procesem projektowym, natomiast dla wykonawców były to zmiany projektu zainicjowane przez właściciela oraz zmiany technologii/metod budowy w celu poprawy wykonalności lub ze względu na warunki terenowe. Przedstawione w artykule wyniki stanowią jedynie wstęp do planowanych badań prowadzonych na większą skalę w przedsiębiorstwach budowlanych w Ukrainie, jednakże przedstawiają już pewien obraz skali tego problemu.

Received 15.04.2019

Revised 30.04.2019 